\title{
Post Conflict Rebuilding: An Exploration of Destination Brand Recovery Strategies
}

\author{
Dr. Reyaz A. Qureshi \\ Asst. Professor, Tourism \& Travel Management, \\ Dept. of Management Studies, University of Kashmir. \\ Dr. Zubair A. Dada \\ Asst. Professor, Tourism Management, \\ Directorate of Distance Education, University of Kashmir.
}

\begin{abstract}
The tectonic shifts that emerged towards the end of the Cold War have metamorphosed the international security agenda. The degeneration of the Soviet Union, the surfacing of nationalist independence movements across the post-communist horizon, and the pulling out of superpower support to prop up friendly regimes throughout the third world unleashed new forces that, among other things, resulted in a considerable augmentation in the number of intra-state wars during the 1990s. By September 11, 2001 at the very latest, it became noticeably comprehensible that intra-state conflicts and their correlation with fragile and failing states - represent not only a major humanitarian apprehension but also a considerable threat to regional and global security. As a result, one of the fundamental challenges facing the international community at the moment involves the prevention and resolution of violent conflicts. Structured tourism in Sri Lanka was inducted in 1966 and Sri Lanka experienced 16 years of swift spreading out of its tourism sector between 1967 and 1982. Arrivals amplified at an average annual rate of more than 20 per cent. However, the tourism trade was sternly impacted by the ethnic violence in mid-1983 and consequently both by the long-dragging ethnic conflict in the North and East of the island and due to insurrection behavior which occurred in areas closer to the tourism operations on the West and South coasts. Therefore, international tourist arrivals kept declining each year placing the trade on a diminishing track. Thus, a political unrest can potentially produce a significant catastrophe since it is capable of impacting negatively the smooth operations of the tourism industry. This paper explores the implications of branding destinations in a post-conflict scenario and the opportunities thereof. Destination branding literature insists that every destination should incorporate crisis management strategies in its tourism planning protocols, management exercises and destination marketing campaigns. This paper proposes that destination branding should be coupled with crisis management strategies for leveraging an opportunity out of crisis, so that, tourism can be a critical catalyst in post conflict reconstruction and overcoming the negative imagery and distrust which still impedes the Sri Lanka's ability to achieve greater political integration and tourism prosperity in an increasingly globalized world.
\end{abstract}

Keywords: Post-Conflict, Rebuilding, Brand Recovery, Crisis

\section{INTRODUCTION}

Among the many roles that tourism plays, perhaps the most important are the opportunity for visitors to experience significant change in their beliefs as a result of direct interaction with people from other places and cultures, and the ability to effectuate meaningful societal change, by de-constructing social stereotypes that often mislead residents and visitors. Whether these transitions occur - and the extent to which they are meaningful for participants - depends on a number of factors applied by tourists when selecting a destination, including the range of available entertainment and leisure activities; the comfort and quality of existing 
accommodations and transportation; the adequacy of the visual scenery and the authenticity of local cultural practices and history; the level of personal risk from disease or threats of terrorism; and the accuracy of information provided to visitors beforehand. In spite of the probable challenges, or perhaps because of them, tourism has reputedly become one of the world's largest - and perhaps the most significant - industries in the post-World War II period, in terms of total employment, land use, and socioeconomic spending. Spurred by increases in personal income levels, more flexible working hours and greater leisure time, along with greater access to affordable transportation and information technology options (such as budget airlines, multi-country train passes, and the Internet), more people now travel both domestically and internationally.

Credited by its proponents with poverty alleviation and long term job creation, an evergrowing list of countries and communities now market themselves worldwide as tourist destinations in hopes of sharing in the profits of global travel, while offering a growing array of options for the travel consumer in activities and facilities (Louillet, 2005). To help the visitor choose from among the many recreational choices, destination branding has become a strategic marketing component with considerable importance in promoting the (re)discovery of tourism destinations severely impacted by global crises, including war, genocide, ethnic and political conflict, disease, poverty, and international terrorism in the post-9/11 world. In these communities, it is a critical tool in resurrecting international travel to countries that seek social security and economic recovery through tourism, and must rely upon a uniquely identifiable brand attraction and targeted visitor niche in the initial stages of market development and recovery. Positive brand images have helped several economies boost their exports and attract investments, businesses, factories, visitors, residents and talented people. On the other hand, an uncountable number of places are unfamiliar to consumers or suffer image problems that impair their ability to compete in the marketplace. In some cases, these images are based on inaccurate information or widespread stereotypes recurrently reinforced by the media and the entertainment industry. In other instances, these images are founded on past episodes of political unrest, natural disasters, violence, and economic downturns. Place images may be clouded by these occurrences much longer than it would take to overcome or correct the problems. Brand management seems to be particularly challenging for emerging, newly industrialized, and transitional nations, including those that have shifted from socialist to free market economic systems. Unfortunately, these experiences are pervasive and afflict myriad places spanning the various regions of the world, such as Latin America, Eastern Europe, Africa, and Asia. While a few places have succeeded in overcoming their image problems and enhancing the equity of their brand names, others still struggle to do so.

\section{DESTINATION BRANDS}

A destination should have a vision. Fabricius (2006) states that a vision that is shared by all the stakeholders and potential consumers should be clearly expressed in the core values of the brand at the launching of the brand. Ooi (2003) emphasizes the actions of monitoring, evaluation and review, which can assist the destination to communicate a clear identity, consistency and a unique brand identity. Destinations should therefore transcend brands in order to create trust marks, a name or symbol that links a destination emotionally with the desires and aspirations of its tourists and ultimately creates love-marks (Morgan et al. 2002). The first stage in the process of building or rejuvenating a destination brand is to establish the destination's core values, which should be durable, relevant and salient for the potential tourist (Heath, 2007). The values should also represent matters that are deliverable, differentiating and enthusing and should resonate with the consumers(Morgan et al. 2004). A destination brand is used in destination marketing primarily to project a positive image of tourism at a destination. While a destination can be considered as a single product comprising of every kind of tourism operation in its geographical area, it can also be viewed legitimately as a composite 
product that comprises a mix of various components (the destination mix) (Morrison \& Anderson, 2002). According to Heath (2004:40), a destination represents a mental picture in the minds of current and potential visitors. Perceptions such as cheap versus exclusive or safe versus dangerous often overshadow reality. Thus, the tourism industry operates in a complex and changing environment that is characterized by several challenges (Heath, 2007).

In most cases, destination marketers have little control over the elements of the destination mix that they are branding. Destination branding plays also a significant role in positioning a destination. When applied to a geographic place, a destination brand may therefore comprise a specific recreational image intended to influence visitor perceptions, and an identity that arguably reflects the prevailing views and values of local users and inhabitants. Whatever its individual features, a destination brand is considered one of the most important tools in international travel when differentiating locally available tourism products and services - and a process increasingly complicated by globalization and the Internet (Graburn, 1995; Anholt, 2006). The proliferation and intensity of these promotional efforts at the local and national levels, as well as the dissimilar results witnessed by competing attractions in visitor totals and investments in the necessary infrastructure and training, reflect the influential role that destination branding can play in differentiating - and profiting - select emergent tourism venues. No longer only an option for local businesses to consider as they search for a global market and recognizable identity, it is now a fundamental requirement for countries who seek to move beyond the conflicts of previous decades through improved communication, trade, and the promotion of international travel. The creation of a national icon is particularly useful in reinforcing legitimate social practices in the state, and in fostering support for targeted investment policies, such as the establishment of appropriate markets, partners, services, and standards for tourism. In this context, a destination brand is intended to generate greater visitation in terms of numbers or specific visitor segments by highlighting proximate leisure activities through descriptive themes and identities. By so doing, adjacent tourist locations are distinguished through social construction and recognition of each place, its people, and its associated attractions. The development of themed (or branded) environments generally goes beyond the de-differentiation of spaces, functions, styles and symbolisms and the deliberate blurring of the real with the artificial and the imaginary. It rests on the effectiveness of the idea of invented landscapes and places and aims at creating contemporary wonderlands of selective nostalgia and pseudo-idealistic visionary (Terkenli, 2006).

\section{OVERVIEW OF LITERATURE}

The tourism literature shows consistency in considering the process of branding a destination as a collaborative effort (Blain, 2001; Deslandes, 2003; Im, 2003; Kaplanidou \& Vogt, 2003; Morgan, Pritchard \& Piggott, 2002; Morgan, Pritchard \& Piggott, 2003). Collaboration in the context of destination branding has been addressed under two different though complementary points of view such as creation of shared image of the destination and the inclusiveness of the process (Blain, 2001). A shared image across all stakeholders is important to ensure consistency in the destination brand image delivered. An image built on shared destination attributes enhances the marketing efforts of a destination (Cai, 2002). Similarly, the sustainability of the positioning of the brand is related not only to the message delivered but also to the degree of shared meanings that is contained in the message (Foley \& Fahy, 2004) The achievement of consistency through shared meanings has been related to the creation of brand equity .(Aaker, 1991; Keller, 1993). In particular, Keller (1998) emphasises that cohesiveness of image is related to the success of a brand and it 'depends on the extent to which the brand elements are consistent. The 'collective phenomenon' of destination branding, has also been described as a 'highly complex and politicized activity' (Morgan et al., 2003) that includes multiple stakeholders (Dinnie, 2002). The need for stakeholders' participation in 
destination branding and the more general importance of participative processes in tourism planning is well recognized and accepted (de Araujo \& Bramwell, 2000; Gunn \& Var, 2002; Jamal \& Getz, 1995; Keogh, 1990; Laws, Scott \& Parfitt, 2002; Marcouiller, 1997; Reed, 1997; Sautter \& Leisen, 1999; Simmons, 1994). Moreover, it has been underlined that it is pointless to plan for tourism without at the same time taking into account the detailed needs of all stakeholders in the area (Laws, 1995). Focusing specifically on destination branding, Prideaux and Cooper (2002) claimed that the destination brand is a positive outcome of the achievement of unity and collaboration among stakeholders. Therefore, the understanding of the process of destination branding requires the comprehension of how different stakeholders carry different and compromise different interests within this process.

Most of the existing literature on tourism crisis has focused largely on terrorism and war without clearly narrowing down to politics as a factor capable of generating a crisis. There is also a plethora of literature focusing on crisis management, but surprisingly there are few sources to turn to regarding politically engineered tourism crisis management. Most tourism crisis strategies that are readily available are found in tourism manuals that address natural disasters. Tourism and politics share a close but often uneasy relationship. Politics, namely, government actions, ideologies and the unfolding of political events can trigger a range of crises. These events shape tourism flows and the environment in which the industry operates. Similarly, tourism impacts political structures and processes since it is a policy arena that offers opportunities to fully exploit economic opportunities and unlock the potential in a country's cultural and natural resources. Once a destination experiences a political crisis there is a tendency for a crisis mind-set to set in. Usually adaptive strategies are adopted which do not seek to change anything, but rather focus on the core of the tourism business, chart alternative action while the going is good and deck when the storm hits. In reality, a political crisis can denote two things: danger or an opportunity. It is prudent to adopt the latter approach. A number of authors have concentrated their efforts on investigations which tend to focus on tourism, crisis management and recovery marketing.

\section{Research Questions}

1. How destinations, conflict \& peace interact with each other?

2. How unfolding of a crisis can be utilized as an opportunity for redeeming destinations?

3. How the study area managed to develop crisis tools to deal with one of the deadliest conflicts?

4. How meta learning among destinations can result in better crisis schooling

\section{Study Area}

\section{Post-Conflict Rebuilding of Destinations-A Case Study of Sri Lanka}

In a post-conflict destination like Sri Lanka, tourism has the potential to not only contribute to economic growth and physical reconstruction, but also to sustainable development, affirmative action and the protection of vulnerable groups. Despite being one of the world's largest industries, tourism is extremely susceptible to the direct and indirect effects of violence. As tourism tends to be more prosperous in peacetime rather than in war time, it is assumed that it would have self-interest in supporting a 'peace dividend'. According to Boutros-Ghali (1995) in the 'Agenda for Peace', post-conflict peace building is an action to identify and support structures which will tend to strengthen and solidify peace in order to avoid a relapse into conflict. This understanding places an emphasis on the immediate post-conflict phase that focuses on issues of capacity building, reconciliation processes and social transformation. Smith breaks down and categorizes peace building activities even further, into four main goals: to provide security; to establish the socio-economic foundations of long-term peace; to establish the political framework of long-term peace; to generate reconciliation, a healing of the wounds of war and justice (2004). Smith illustrates his definition through a 'peace building 
palette' which incorporates specific, yet overlapping activities within the four issue areas. Figure below shows the complex interrelationship between different dimensions of peace building and to help identify how specific efforts make a contribution to long term goals of peace.

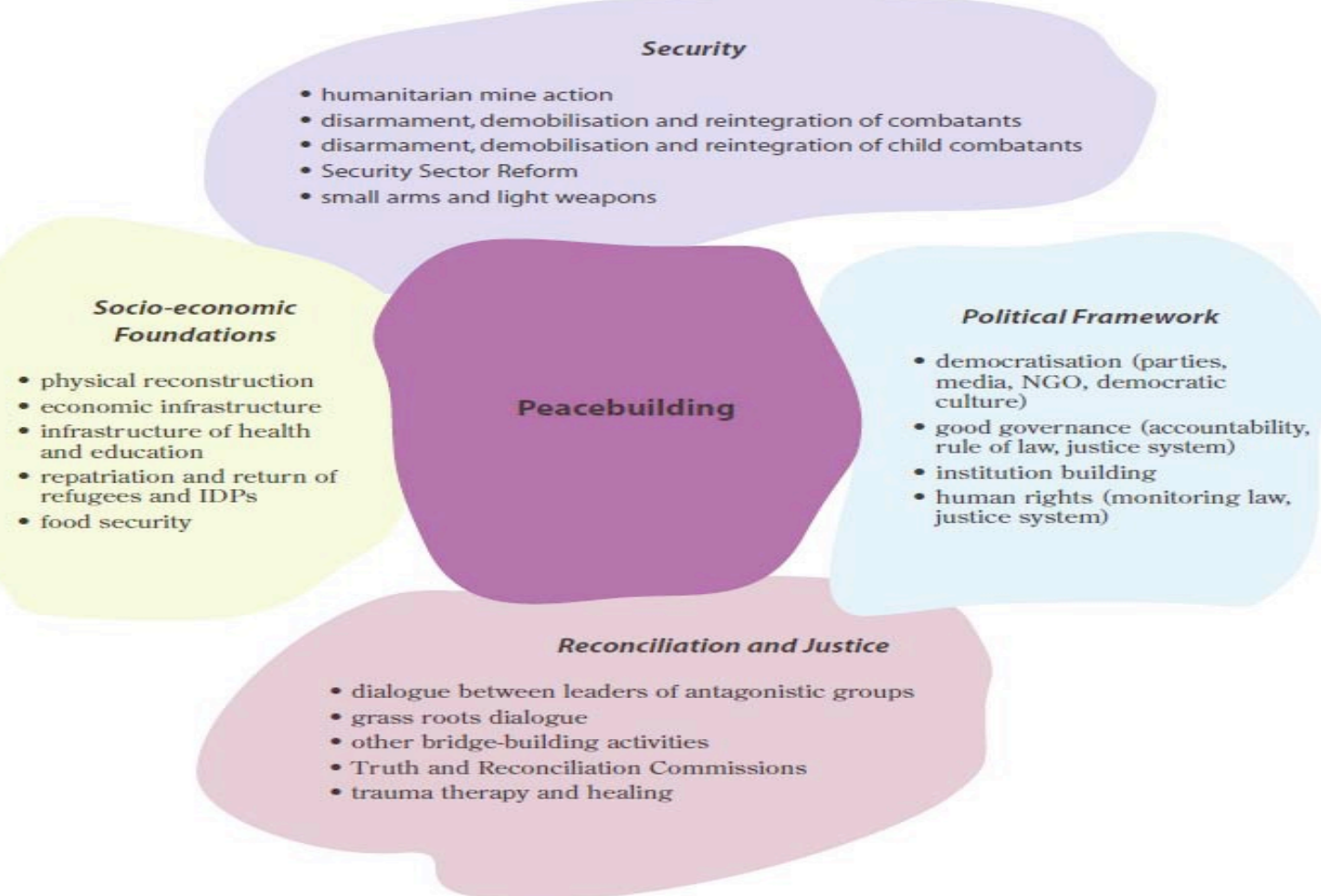

Source: The Peace building Palette. Adapted from Smith, 2004

Post-conflict reconstruction is strongly interlinked with peace building activities, and tends to focus on issues related to physical reconstruction, economic recovery, institution building and social integration, falling mostly into issue areas of socio-economic foundations and political framework. The World Bank defines post-conflict reconstruction as the rebuilding of socioeconomic frameworks of society and the reconstruction of the enabling conditions for a functioning peacetime society, explicitly including governance and rule of law as essential components (1998, in UNDP 2006). Both peace building and post-conflict reconstruction are important in supporting socio-economic, political, security and reconciliation processes in Sri Lanka whilst helping to reduce the risk of conflict recurrence.

What are the impacts of armed conflict on a tourism sector? How can the tourism sector cope with the impacts of armed conflict and sustain itself? How can it further revive the industry, improve its image, and act as catalyst for peace so that peace in turn becomes a dividend for tourism? Sri Lanka was a popular destination but a decade-long armed conflict caused it to become crisis-ridden, and it is now in the process of reviving its destination image. It serves as a concrete illustration of the nexus of tourism, conflict and peace. Fluctuations in international tourist arrivals in response to the absence of peace and occurrence of conflicts affect developed and developing countries (UNWTO, 2006). However, developing countries are more vulnerable as they possess fewer resources and mechanisms to mitigate the impacts.

Sri Lanka, a developing country in the Asia Pacific region, is a very good case study of such vulnerability that had been entwined in a tripartite matrix involving conflict, tourism, and peace. Sri Lanka's time-honored culture and generally unblemished natural ecology are prime pull factors for diverse tourist market segments such as holiday-seeking luxury tourists, 
pilgrims, adventure seekers, and special interest tourists across the globe. Since opening the country to tourists in 1966, Sri Lanka experienced 16 years of swift spreading out of its tourism sector between 1967 and 1982. Arrivals amplified at an average annual rate of more than 20 per cent. However, the tourism trade was sternly impacted by the ethnic violence in mid-1983 and consequently both by the long-dragging ethnic conflict in the North and East of the island and due to insurrection behavior which occurred in areas closer to the tourism operations on the West and South coasts. Therefore, international tourist arrivals kept declining each year placing the trade on a diminishing track. Thus, a political unrest can potentially produce a significant catastrophe since it is capable of impacting negatively the smooth operations of the tourism industry. This potentially can have a substantial negative impact on the tourism sector, which in turn can affect other economic and non-economic elements throughout the country. However, in a post-conflict destination like Sri Lanka, tourism has the potential to not only contribute to economic growth and physical reconstruction, but also to sustainable development, affirmative action and the protection of vulnerable groups. Tourism, conflict and peace exist in a reciprocal triangular matrix in which each impact on the others as illustrated by the framework.

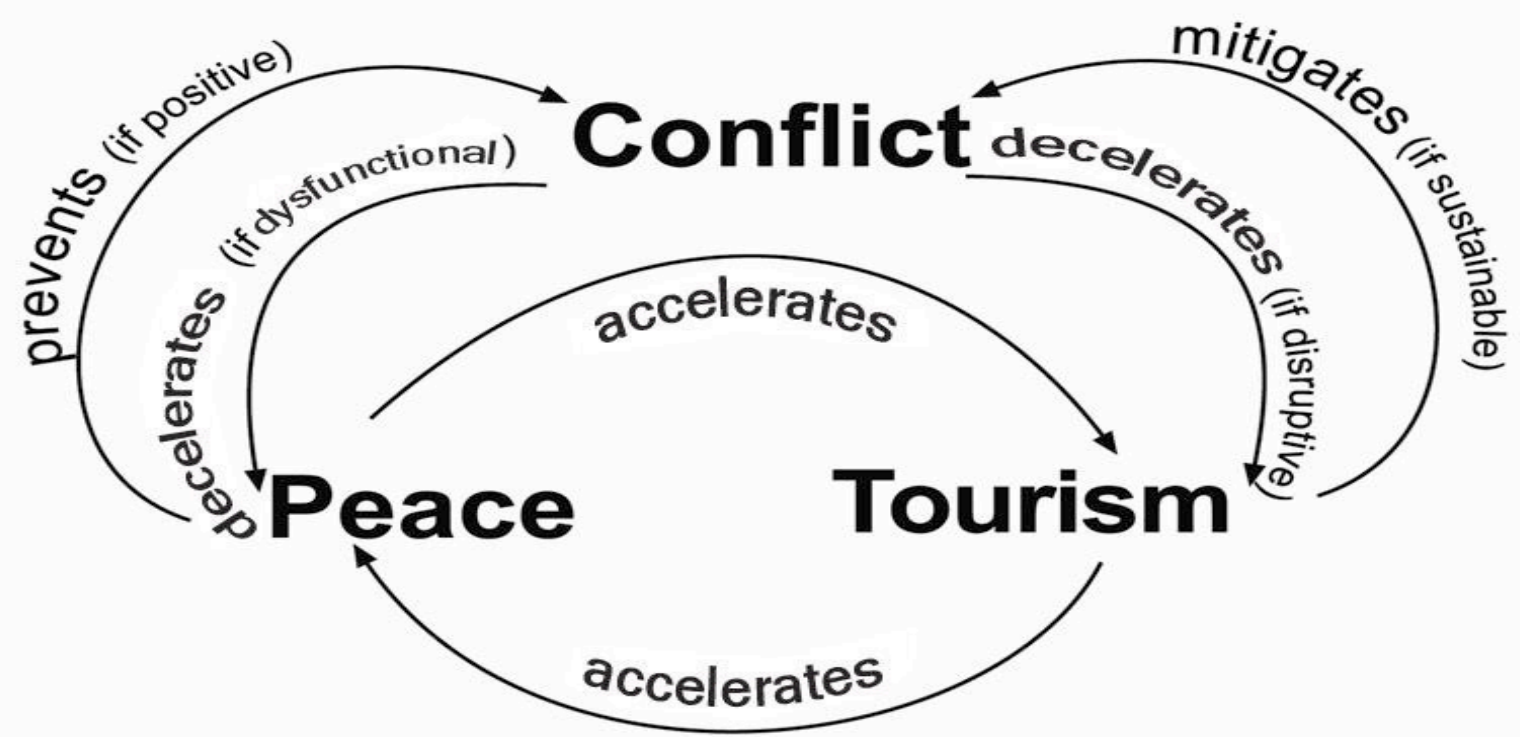

Source: Upadhayaya, 2008 (A conceptual framework for the interrelationship of peace, conflict and tourism)

Conflict, a state of dispute and distrust, decelerates sustainable growth of the tourism sector if it leads to violence and threatens peace. However, minor conflicts which are manageable have often been conducive to peace if the issues are addressed in a timely manner and involve cooperation among the stakeholders.

Destinations are less appealing to tourists if they are insecure or likely to experience serious conflict (Alluri, 2009) - war, political unrest, terrorism, violations of human rights or heavy crime - regardless of the abundance of scenic or cultural attractions (Sonmez, 1998) as was the case for Sri Lanka. Although there are instances of tourist attractions based on war and atrocities, tourism in general is highly vulnerable to turmoil and can thrive only under peaceful conditions (Mihalic, 1996; Neumayer, 2004; Pizam and Mansfeld, 2006; Tarlow, 2006). Tourism is perceived as an approach which can supplement social and political reconciliation efforts in post-conflict settings. If tourism is operating with sustainable principles and practices, it can have positive impacts in reducing tensions between visitors and host communities. The significance of sustainable tourism (which is listed as one of the 21 key areas in sustainable development by the UN Division for Sustainable Development) is also associated with its potential for poverty eradication and peace building, emphasized in the UNWTO"s 
Sustainable Tourism-Eliminating Poverty (ST-EP) programme (Upadhayaya \& Sharma, 2010). The potential role of tourism in contributing to peace from socio-cultural, political, human rights, social justice, environmental (climate change), corporate social responsibility, health, globalization, intergenerational tourism, and alternative tourism perspectives has been discussed (D' Amore, 1988, 2007; Din, 1988; Eriksson, Noble, Patella and Barnett, 2009; Hall, 1994; Higgins-Desbiolles, 2003; Higgins-Desbiollles and Blanchard, 2010; Issac, 2010; Leitner, 1999; Mihalic, 1996; Nielsen, 2001; Tarlow, 2006; Upadhayaya \& Sharma, 2010). The relationship between tourism and peace has also been endorsed by a number of institutions. Such initiatives highlight the co-relation and causal relationship between tourism and peace, and support the theory that tourism can be helpful in mitigating conflict and accelerating peace. Peace is a state that not only indicates the absence of direct violence but also sustains peaceful relationships among all levels and segments of society and between society and nature. It is based on human rights, economic wellbeing, and socio- political equality for all the people. It is also found to have a direct relationship with tourism (Bhattarai and Dahal, 2007; Grandon, 2007; NTB, 2008b; Upadhayaya, 2008b; Upreti and Upadhayaya, 2009).

The Democratic Socialist Republic of Sri Lanka was called Ceylon until 1972. In ancient sources it is referred to as Lanka, Taprobane and also as Serendib. As a tourism destination it indeed has everything to ensure 'serendipity': for making happy and unexpected discoveries. Despite its size of only 65,525 square kilometers the island offers a wide variety of landscapes and great natural beauty: from picturesque beaches to impressive mountains, from rainforests to red desert-like plains, from spectacular botanical gardens to unique wildlife. The profusion of heritage and cultural attractions, including seven UNESCO World Heritage sites, means the tagline "Sri Lanka- Small Miracle.

Sri Lanka Tourism launched its new brand with a new tagline and logo expected to usher in a new era for Sri Lanka Tourism across the world. The new brand - Sri Lanka Small Miracle - the positioning that was conceptualized following months of research by A C Nielson and strategic planning sessions will replace the current tagline "Sri Lanka, Land like No other" As part of the communication campaign many promotions, road shows and press conferences were planned across the fifteen cities in ten countries - a move that is expected to attract and generate more tourists into the island. Mr. Dileep Mudadeniya, Managing Director of the Sri Lanka Tourism Promotion Bureau said "The objective of the Sri Lanka Tourism re-branding exercise was to create a single core idea that can change people's perception of the country. The challenge faced by Sri Lanka Tourism during the brand strategy planning session in 2006 was to find an idea that embraces the truth of the country which is relevant to the potential visitor; then communicate that idea through every material item that produced thus establishing an integrated marketing communication approach." Sri Lanka Tourism's new brand positioning is "One of the many unfathomable mysteries of Sri Lanka as to how it manages to squeeze so many different features. The positioning strategy was arrived at based on the key aspects of the destination - Diverse, Compactness, Authenticity and Island which differentiate the destination from other competitors.

The unique selling proposition of the brand is based on the concept that in tourism marketing we are marketing an intangible product - a dream. Destination Representation Companies (DRC) were appointed in key markets - namely in Middle East, France, Germany, Russia and India to implement the creative execution of the new brand positioning. A soft launch of the rebranding took place at ITB in Berlin and has subsequently been extended to its key markets including the Middle East, the U.K, France, Russia and India as well as its growth markets of Italy, Japan, and China. In addition a cyber competition - a competition for the blogging community has been planned to be launched during this. In keeping with government policy 
and in consultation with the industry Sri Lanka tourism has given special concessions for the SME sector to participate in international fairs. The process to develop the new brand began as far back as 2004 when with the participation of all the stake holders strategic planning and brain storming sessions were conducted and also debates made on many aspects were discussed and agreed. Similar sessions were held subsequently in 2008. The brand launch coincides with the new era of peace that Sri Lanka is expecting in the coming future, following the victories of the government forces against the LTTE. The Sri Lankan Government is positive about the post war scenario and is looking at a marketing strategy for Sri Lanka Tourism. With such development activities taking place within the entire island, Sri Lanka which boasts of diverse offerings - be it miles of palm fringed beaches, cool tropics of the hill country, wild life or city life within a tiny compact island, will go back to its old charm of a safe tropical island - the way it was known many years ago. What other tagline would be apt for Sri Lanka other than - small miracle!

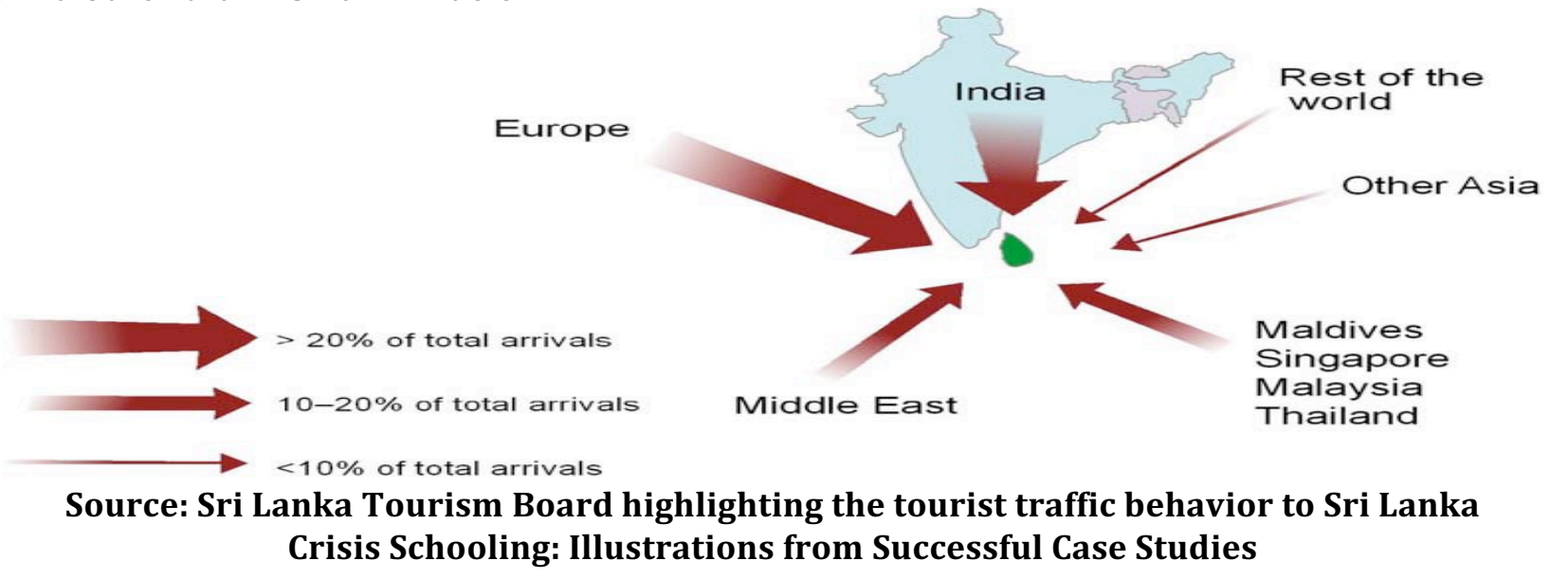

\section{Bali 2002}

Tourism is the backbone of Bali and accounts for almost $50 \%$ of the Island's economy (Lynch 2004:109). Bali was a popular world destination for tourism and business travelers, with a reputation as a safe haven and is known as 'The Island of the Gods'. Of the 5 million visitors to Indonesia in 2002, 1.5 million entered at Bali's international airport.

\section{The Attack}

On October 12th, 2002 two bombs went off in a busy nightclub area of Kuta, Bali, killing 202 people, mostly foreign tourists. Citizens from 21 countries, the majority holiday makers, were killed in the blast, including 88 Australians, 26 Britons, five Swedes, seven Americans, six Germans and four Dutch nationals. Significantly, the attack took place just as the tourist season in Bali began (November). Therefore, the attack had the potential to significantly affect the travel plans of millions and damage a complete tourist season.

\section{The Reaction}

The attack in Bali had a knock on effect in Australia 'shattering the continent's sense of safety in isolation' (Squires 2002:22). The bombing appeared to instill an immediate fear of further attacks in Australia and possibly beyond. According to Bareham (2004:160) visitor numbers to Bali dropped by $60 \%$ between October and November 2002. The UK Foreign Office issued a travel advisory warning its nationals not to travel, which in turn had a devastating effect on tourism to the island (CNN, 2002). However, according to Baroness Amos (Foreign Office Minister for Consular Affairs UK) 'travel advice is designed to provide travelers with practical, objective and up-to-date advice about that destination ...and representation by the travel industry cannot and do not influence our decisions' (Tourism Concern Spring 2003: 9). This last point is worth noting as it suggests that in certain cases, the tourism industry may in fact be powerless to affect and protect, to the extent to which it would like, the viability of the industry in the immediate aftermath of an attack. Faced with these circumstances after the 
bombings, tour operators scaled down operations in Bali in the immediate term. However, the full term impacts of the attacks would last much longer (CNN 2002) as tourists began to switch destinations, from Bali (Indonesia) to Phuket in Thailand (www.hotelonline.com). While tourists may have been forced by the travel advisory to amend their destination plans, they appear not to have changed their travel plans altogether, according to Chief Executive of the Association of British Travel Agents, who said that people due to go to Bali readily accepted other destinations in the region instead, including Malaysia and Singapore. 'People still seem determined to get away,' he said, and predicted that 'any down turn that did emerge [after the Bali bombings] should be short-lived'. Confidence in Bali as a destination was reflected in the reaction of TUI, Europe's biggest travel group in Germany, which commented that 'there is a process of getting back to normal after a certain time' and said it would not send any customers to Bali for a week as a precautionary measure after the bombings.

\section{The Response}

In the Spring of 2003 The 'Back to Bali' Campaign was launched with the aim of regaining 'consumer confidence both internationally and domestically and to improve Bali's image as a safe, enjoyable and attractive destination to visit' (Bachrie, 2003). There was a belief that security issues and price were not connected, so no bargains were offered according to Marriott (2003). According to Travel Retailer International (2005) 'Bali is a good example of the resilience of popular tourist destinations. The island's tourism industry made a strong recovery following the bombings', reporting that the Japanese, 'who are easily deterred from visiting potentially unsafe destinations, are back. The WTO (2003) commented that the tragedy did not have a tremendous effect on Indonesia's tourism statistics, with Bali reporting a 2.2 per cent fall in international tourist arrivals. The WTO suggested that the international support and the Indonesian government's immediate and professional reaction subdued the effects of the attack. Within a month of the attacks suspects were arrested and in February 2003, 4 months after the attacks the alleged mastermind behind the bombings was prosecuted.

\section{London, 2005}

The United Kingdom (UK) had experienced a steady increase in international arrivals year on year since 1985. In 1995, the UK recorded significant increases (13.2\% on the previous year), coinciding with the Northern Ireland Peace Agreement. The years 1999 and 2000 showed a small downturn in visitor numbers (- $1.4 \%$ and $-0.7 \%$ respectively). International visitor numbers dropped for a third year in a row (though by a far greater amount: $-9.4 \%$ ) in 2001, the year of a major Foot \& Mouth Disease outbreak in the UK, as well as the attacks of 9/11. It took until 2004 for international figures to surpass the numbers recorded in 2000, with a significant increase recorded in 2004 of $+12.3 \%$ on the previous year. According to Price Waterhouse Coopers (2007: 6) 'tourism is one of the key drivers of London's economy, accounting for around 10 per cent of GDP and providing 10 per cent of employment'.

\section{The Attack}

On July 7th 2005, a series of bombs exploded on London's transport system in a coordinated attack during the morning rush hour. At 8.50am, three bombs exploded on the city's underground transport network. At 9.47am, a fourth bomb was detonated on a London bus. The attacks killed 52 civilians, plus four suicide bombers, and injured approximately 700 people. The incident, which came the day after London was chosen as the site of the 2012 Olympics and on the morning of the opening of the G8 Summit in Scotland, was the deadliest single act of terrorism in the UK since Lockerbie (1988, 270 deaths). Metropolitan Police Commissioner Ian Blair described the attacks to reporters as the 'the biggest crime scene in English history' (BBC News, 2005). 


\section{The Reaction}

Immediately after the attacks, Police Commissioner Blair reassured people that an emergency plan was in place and the situation was 'steadily coming under control'. News coverage was uninterrupted throughout the day until $7 \mathrm{pm}$. Bus services in London resumed by $4 \mathrm{pm}$ the same day, while most underground rail services reopened the following morning. Regional attractions and seaside resorts reported an increase in holiday trade as domestic tourism moved out of the capital in the immediate aftermath of the attack (Kirkham, 2005:7). A 10\% drop in business in 2 and 3 star city properties correlated with an increase of $10 \%$ in the regions. Short break travel to London from Europe and other parts of the UK also experienced a decline. According to Timmons (2005:23-24) 'weekend travel to London from Europe and other parts of the UK is down about 7 percent since July 7th bombings' (as of July 23rd), while some travelers intending to visit London have 'switched hotel reservations to outside of central London'. In a move to address the immediate decline in numbers, London used a marketing campaign around the country to tell people that London is 'open for business' with a series of festivals and free events in the following September.

\section{The Response}

Travel Retailer International (2005) predicted that London would experience a significant drop in US visitor numbers as 'Americans, one of London's key visitor groups, are sensitive to risk'. At the end of July 2005, experts were concerned that while people were not cancelling trips, they were not booking them either (Kirkham, 2005). In particular, the North American, Japanese and Australian markets were performing 25\% below expectations. Nevertheless, the entire twelve months of 2005 saw the highest number of overseas visitors to the UK ever recorded, at 30 million. Visitor spending reached $£ 14$.2billion, an increase of 6 per cent from 2004 (ONS, 2006). By 2007 the outlook for tourism remained positive. Price Waterhouse Coopers remarked (2007: 1) that "the good times are rolling", but warned that the sector's current buoyancy remained fragile as the risks of unforeseen events remain and we are only ever a scare away from the declines that regularly impact the sector. Embracing and managing risk is likely to be a key differentiator in the future'. Henderson (2007: 66) commented that efforts were made to 'stress that the terrorist threat was not confined to the island but universal' reinforcing the point that 'living life as normal represents a gesture of defiance against terrorists and may contribute to their ultimate defeat'.

\section{DISCUSSION, SUMMARY AND CONCLUSION}

The working environment for tourism changed dramatically in recent years and particularly in Sri Lanka per se. Ever going political and ethnic conflicts have become one of the predominant external threats to international travel, and the industry needs to face up to the fact that Political terrorism is now an integrated risk of contemporary travel and will have to learn how to deal with it (Gold and Holland ,2001). The level of devastation a destination will suffer after a long dragging violent conflict depends to a greater extent on the destination's resilience and on the recovery strategies of the stakeholders. There are a number of factors that can be reasoned out from the case studies referred that control the impact a violent outbreak has on a tourism destination and that will eventually decide out the restoration process. While US interests have often been the target of attacks worldwide, prior to 9/11 there had only been two terrorist attacks in the last 14 years on the American soil. These were the bombing of the WTC (1993) and the bombing in Oklahoma in (1995). The deficiency of expertise for this sort of contingency and the authorities' ensuing responses may have hindered the restoration process. The other two case studies all had experience of political unrest, which included terrorist attacks, making them relatively well-schooled in post-conflict strategies and responses. 
The government's role in the tourism industry in general and their role in managing the crisis, props up as a significant support system in the crisis management process. Prideaux et al. (2003) concur with this stating that the government's response to crisis may be a critical element in the manner in which national tourism industries cope with declining tourism flows. The sketch of the tourism industry can facilitate or obstruct the synchronized efforts vital to lever a crisis. The US, as mentioned earlier, does not have a committed ministry in tourism, while other destinations in question have a more articulated tourism portrait, which streamlines a synchronized effort. Considerable participation is needed from the public sector to sponsor marketing campaigns in Sri Lanka. An instantaneous, rapid and professional response is needed from government in levering the crisis at hand in order to restore a measure of confidence amongst the prospective travelers that it is safe to visit Sri Lanka. It has been observed that heads of state visited Madrid in the immediate aftermath of the 2004 bombings, implicitly acknowledging a reassertion of normality and return of control. In Indonesia, Spain and UK, arrests relating to the attacks were made in the weeks immediately following the bombings. However, in the US no immediate arrests were made. The US invaded Afghanistan within four weeks of $9 / 11$, which served to intensify global uncertainty and increase fear of international repercussions. In the cases above, modes of transport were used to facilitate the terrorist attacks - planes, trains and buses. This use of transport to facilitate terrorist attacks has been highlighted by Henderson (2007). All attacks were decisively synchronized and simultaneous bombings were affected to ensure maximum chaos and devastation. According to the WEF (2007), the cost of terror operations are inexpensive. This could imply that the amount of devastation caused (measured in physical and economic damage as well as an increased climate of fear amongst civilians and governments) makes a terrorist attack 'value for money', in turn implicating that further attacks are far from unlikely. While there have been security measures put in place to improve air travel, it is difficult to enforce security measures on public transport such as buses, trains and undergrounds.

In this new era of insecurity the tourism industry in Sri Lanka must be prepared to acknowledge the phases of crisis recovery, maintain flexible structure to manage a crisis and be capable of managing the media who have a high interest in covering these horrific events. There are defining phases in crisis recovery - immediate shock, initial reaction and considered responses. By acknowledging these phases, the Sri Lankan tourism industry can prepare for each phase with appropriate response measures.

Therefore, it is worth considering that destination branding coupled with effective crisis communication is a powerful tool for repositioning Sri Lanka as an attractive and safe destination and, thereby, an effective mechanism for post-conflict reconstruction. However, destination branding can be affected by a number of factors including politics. Politics stretches far beyond the power of branding. It has been demonstrated clearly that in a possible crisis situation, Sri Lanka needs to consider other strategies like public diplomacy, crisis management, isolationist strategies and be able to use some of the risk management tools available in order to avert possible turbulent situation. The aim should be to convert a political risk into an opportunity through the use of opportunity management strategies. Therefore, it is recommended that Destination Management Organizations should focus on positive aspects of a crisis by extracting the positive aspects, focusing on the difference the crisis has caused and any special circumstances. Re-branding a destination during a crisis will not yield any substantial dividends since destinations cannot be re-named like commodities but Destination Marketing Organizations in Sri Lanka need to re-learn the crisis situation and rethink on how they can use it as an opportunity.

\section{References}


Aaker, D. (1996). Building strong brands. New York: Free Press.

Aaker, D.A. (1997). Dimensions of brand personality. Journal of Marketing Research, 34(3): 347-356.

Aaker, D.A. (2001). Strategic marketing management. 6th ed. New York: Wiley \& Sons.

Alfonso Gonzolez-Herrero, Cornelius Pratt. (1998). Preventive marketing for crisis communications in tourism. Management strategies in the USA and Spain. Journal of Communication Management.Vol. 3 Iss. 1. pp. 9 - 25

Alluri, R.M. (2009). The Role of Tourism in Post-Conflict Peacebuilding in Rwanda. Bern: Swisspeace.

Anderson. J. (1983). The Equity of Cognition. Harvard University Press. Cambridge MA.

Anholt, S. (2003). Branding Places and Nations. In T. Clifton, and S. Simmons (Eds.), Brands and Branding (pp. 213226). London: Profile Books.

Anholt, S.(2005). Brand New Justice. How branding places and products can help the developing world. Oxford: Elsevier Butterworth-Heinemann.

Anholt, Simon. (2006). Nation branding: Introduction. Journal of Brand Management March: 1.

Bareham, J. R. (2004) 'Can consumers be predicted or are they unmanageable', International Journal ofContemporary Hospitality Management, vol.16, no. 3, pp.159-165.

Bar-On, R. (1997) Databank: EuropeTourism Economics vol. 3, pp. 399-411.

BBC News (2003) 'Bali death toll set at 202', BBC News, Feb 19, 2003 http://news.bbc.co.uk/go/pr/fr//1/hi/world/asia-pacific/2778923.stm, [27/2/2003].

BBC News (2004) 'Scores die in Madrid bomb carnage', BBC News, Mar 11, 2004 http://news.bbc.co.uk/go/pr/fr//1/hi/europe/3500452.stm, [15/3/2004].

BBC News (2005) 'Blasts cast shadow over Egypt's recovery', BBC News, July 23, 2005

http://news.bbc.co.uk/go/pr/fr/-/1/hi/world/middle_east/4710431/stm, [27/7/2005]

BBC News (2005) 'London rocked by terror attacks' BBC News, July 7, 2005 http://news.bbc.co.uk/go/pr/fr//1/hi/uk/4659093.stm, [17/7/2005].

Beirman, D. (2003) Restoring Tourism Destinations in Crisis, UK, CABI Publishing, p4-58.

Bieger, T. (2008). Management von Dienstleistungen. München. Oldenbourg.

Blain, C., Levy, S. E., and Ritchie, J. R. B. (2005). Destination branding - Insights and practices from Destination Management Organizations. Journal of Tourism Research. 43(3) 328-338.

Blichfeldt, S.T. (2003). Unmanageable destination brands. Esbjerg: University of South Denmark.

Boutros-Ghali, B. (1992). An Agenda for Peace. A/47/277.

Buhalis. D. (2000), "Marketing the competitive destination of the future”, Tourism Management, Vol. 21, pp. 97116.

Cai Liping A. (2002), “Cooperative branding for rural destination”, Annals of Tourism Research, Vol.29, No. 3, pp. 720-742.

Cai, L. A. and Bai. B. (2003). Destination image and loyalty. Tourism Review International, 3(4), 153.

Chon.K-S (1990).The Role of Destination Image in Tourism. A Review and Discussion. Revue du Tourism.Vol.2, pp. 2-9.

Clarke. J. (2000). Tourism brands: An exploratory study of the brands box model. Journal of Vacation Marketing, Vol. 6, No. 4, pp. 329-345.

CNN (2002) .Devastating blow to Bali tourism. CNN.com, Oct 13, 2002

http://archives.cnn.com.2002.WORLD/asiapcf/southeast/10/13/bali.tourism/index.html, [20/13/2002]

Connor N.O., Stafford M.R, Gallagher G. A chronological review of the tourism industry's reactions to terrorist attacks. using Bali (2002). London (2005). Madrid (2004) and New York (2001) as case studies.

D’Amore, L. (1988). Tourism - A vital force for peace. Annals of Tourism Research, 15(2), 269-71.

Enders, W. and Sandler, T. (2001). Patterns of Transnational Terrorisms. 1970-99, p1-4.

Eriksson, J., Noble, R., Pattullo, P., \& Barnett, T. (2009). Putting Tourism to Rights - A Challenge to human rights abuses in the tourism industry. London: Tourism Concern. 
Fischer III, H. (2005). The danger in over-reacting to terrorism. Disaster Prevention and Management, vol. 14, no.5, pp.657-665.

Foley, A., Fahy, J. (2004).Incongruity between expression and experience. The role of imagery in supporting the positioning of a tourism destination brand. Journal of Brand Management, Vol. 11, $\mathrm{N}^{\circ}$ 3, pp. 209-217, February.

Gartner, W. C. (1993). Image formation process. Journal of Travel and Tourism Marketing, 2(2/3),191-215.

Gertner, David (ed.)(in progress). The challenge of place branding in emerging, transitional, negatively viewed and newly industrialized nations. Place Branding.

Gilham, R. (ed) (2001) Tourism and the Media, Australia. Hospitality Press Pty Ltd, p146-162.

Gold, M. \& Holland, M, 2001, PKF Hotel Consultancy Services UK Opinion Piece, [Online]

Available:http://www.hospitality net.org/news/4009872 [08/10/2002].

Guardian Newspaper (2001) http://www.guardian.co.uk/comment/story/0,3604,525945,00.html [27/7/2001]

Gunn, C. A., and Var, T. (2002). Tourism Planning - Basics, Concepts, Cases. New York: Routledge.

Hall, D. (2002) Brand development, tourism and national identity. The re-imaging of former

Yugoslavia.The Journal of Brand Management 9(4-5): 323-334.

Heath, E. 2004. Strategic Destination Marketing: Principles and Practices. Unpublished Report. University of Pretoria.

Henderson, J.C. (2007) Tourism Crises - causes, consequences and management. Oxford. Butterworth- Heinemann.

Higgins-Desbiolles, F. (2003). Reconciliation Tourism: Tourism Healing Divided Societies! Tourism Recreation Research, 28(3), 35-44.

Higgins-Desbiolles, F., \& Blanchard, L. (2010). Challenging Peace through Tourism: Placing Tourism in the context of Human Rights, Justice and Peace. In O. Moufakkir., \& I. Kelly (Eds.), Tourism, Progress and Peace (pp. 35-47). Wallingford: $\mathrm{CAB}$ International.

Holland, M. and Gold, M. (2001) Bloodied but unbowed - Tourism's battle with terrorism, UK, Oct 18, 2001, PKF.

Howie, F. 2003. Managing tourism destinations. London. Thomson

Issac, R. K. (2010). Palestinian Tourism in Transition: Hope, Aspiration, or Reality? In O. Moufakkir., A. Gelbman., D. Timothy., \& I. Kelly (Eds.). The Journal of Tourism and Peace Research (pp. 16-26). Stenden University: The International Centre for Peace through Tourism Research.

Jamal, T. B., and Getz, D. (1995). Collaboration theory and community tourism planning. Annals of Tourism Research, 22(1), 186-204.

Joachimsthaler, E. Aaker, E, (1997). Building brands without mass media. London: Harvard Kogan Page.

Joram Ndlovu, Elias Nyakunu, Ernie, T. Heath(2009). Branding a destination in a political crisis. Re-learning, rethinking and realigning strategies. NJLC, Volume 3: Number 2, December 2009

Keller, K. L. (1993). Conceptualizing, Measuring, and Managing Customer-based Brand Equity. Journal of Marketing, 57(1), 1.

Keller, K.L.( 2003). Strategic brand management: Building, measuring and managing brand equity. (edn). Upper Saddle River, New Jersey: Prentice Hall.

Kirkham, S. (2005). Thousands switch to regional attractions. The Guardian, Aug 8, 2005, p7.

Kirkham, S. (2005). London feels the chill as takings fall. The Guardian, July 30, 2005, p7.

Laws, E.( 2002). Tourism marketing, services and quality management perspectives. London: Stanley Thorns.

Leitner, M.J. (1999). Promoting Peace Through Intergenerational Tourism. Tourism Recreation Research, 24(1), 53-56.

Louillet, Marie Claire (2005) Proposal for a success model for destination management systems. Unpublished Ph.D. dissertation, Faculty of Business Administration, Sherbrooke University, Canada.

Lynch, M. (2004) Weathering the Storm, Leicester, Matador.

Morrison, A. M., \& Anderson, D. J., 2002. Destination branding, paper presented to the Annual Meeting of the Missouri Association of Convention and Visitor Bureaus. 
Mansfeld, Y. (1995) 'War, Tourism and the Middle East Factor', Security \& Risks in travel and tourism,Sweden, p109.

Mansfeld, Y. (1999) 'Cycles of war, terror, and peace: determinants and management of crisis and recovery of the Israeli tourism industry', Journal of Travel Research, vol. 38, no. 1, pp. 30-37.

Mansfeld, Y and Pizam, A. (2006) 'Tourism, Security and Safety from theory to practice', Elsevier Butter-Heinemann, Oxford.

Marriott, S. (2003) 'When travel spells trouble', The Irish Times, Jan 8, 2003, p13.

Middleton, V.T.C \& Clarke, J.(1998). Marketing in travel and tourism. New York: Butterworth-Heinemann.

Midleton, V.T.C. \& Clarke, J. (2001). Marketing in travel and tourism. (3rd ed). Oxford: Butterworth-Heinemann.

Morgan, N. Nigel, Pride, R. \& Prichard, A. (2002). Destination branding: Creating a unique destination proposition. Chichester: John Wiley \& Sons.

Morgan, N. J., Pritchard, A., and Piggot, R. (2003). Destination branding and the role of the stakeholders - the case of New Zealand. Journal of Vacation Marketing, 9(3), 285-299.

Morgan, N. J., Pritchard, A., and Pride, R. (2004). Destination branding - creating the unique destination proposition. Oxford: Elsevier-Butterworth-Heinemann.

Mowforth, M. (2003) 'Tourism, Terrorism and Climate Change' paper prepared for NATO Advanced Research Workshop, Warsaw, Poland, 6-8 Nov 2003

Mihalic, T. (1996). Tourism and warfare - the case of Slovenia. In A. Pizam \& Y. Mansfeld (Eds.), Tourism, Crime, and International Security Issues (pp. 231- 246). Chichester: John Wiley \& Sons Ltd.

Neumayer, E. (2004). The Impact of Political Violence on Tourism. Journal of Conflict Resolution, 48(2), $259-281$. Nielsen, C. (2001). Tourism and the Media. Melbourne: Hospitality Press Pty Ltd. NTB. (2008b). In focus 2008. Kathmandu: Nepal Tourism Board (NTB).

Prideaux, B. (2003) 'The need to use disaster planning frameworks to respond to major tourism disasters',Journal of Travel \& Tourism Marketing, vol. 15, no. 2/3/4, pp. 281-298.

Prideaux, B., Laws, E. \& Faulkner, B. (2003) 'Events in Indonesia: exploring the limits to formal tourism trends forecasting methods in complex crisis situations', Tourism Management, vol. 24, pp. 475-487.

Price Waterhouse Coopers (2007) Hospitality Directions Europe Edition, Mar2007, Issue 15, PWC.

Ritchie, B.J.R. and Crouch G.I. (2000). The competitive destination: a sustainable perspective. Tourism Management 21(1): 1-7.

Ritchie, J. R. B., and Ritchie, R. J. B. (1998). The Branding of tourism destinations: Past achievements and future challenges. In Destination Marketing: Scopes and Limitations,

Peter Keller (ed.). Proceedings of the 1998 Annual Congress of the International Association of Scientific Experts in Tourism, Marrakech, Morocco, August 26-September 5; 89-116.

R. Upreti., S.R. Sharma., K.N. Pyakuryal., \& S. Ghimire (Eds.), The Remake of a State, Post-conflict Challenges and State Building in Nepal (pp. 87-109). Kathmandu: South Asia Regional Coordination Office of the Swiss National Centre of Competence in Research (NCCR North-South) and Human and Natural Resources Studies Centre, Kathmandu University.

Ryan, C. (1991) 'Tourism, terrorism and violence - the risks of wider world travel', Conflict Study 244, Research Institute for the Study of Conflict and Terrorism, London

Smith, D. (2004). Towards a strategic framework for peacebuilding: Getting their act together. Royal Norwegian Ministry of Foreign Affairs: Evaluation Report 1/2004.

Sonmez, S.F. (1998). Tourism, Terrorism and Political Instability. Annals of Tourism Research, 25(2), 416 - 456.

Sonmez, S.F., Apostolopoulos, Y., \& Tarlow, P. (1999). Tourism in Crisis: Managing the Effects of Terrorism. Journal of Travel Research, 38, 13 - 18.

Sonmez, S. \& Graefe, A. (1998). Influence of terrorism risk on foreign tourism decisions. Annals of Tourism Research, (25): 112-144

Tarlow, P.E. (2006). A Social Theory of Terrorism and Tourism. In Y. Mansfeld., \& A. Pizam (Eds.), Tourism, security and Safety (pp. 33 - 47). Oxford: Elsevier. 
Tarlow, P. \& Santana, G.( 2002). Providing safety for tourists: A study of selected sample tourist destinations in the United States and Brazil. Journal of Travel Research, 40 (4): 424-432.

Toyne, S. (2001) 'What now for Tourism?' BBC News, Sept 18, 2001, http://news.bbc.co.uk/1/hi/business [03/04/2004].

Travel Retailer International (2005) 'Winning the War against Terrorism', Travel Retailer International, Sept-Oct 2005, p64 (2), Euro money Institutional Investor PLC.

Upadhayaya, P.K. (2008a). Role of Tourism in Conflict Mitigation and Peace Building: A Case study of Nepalm. Unpublished PhD research proposal, Kathmandu University. Nepal. Upadhayaya, P. K. (2008b). Lasting Peace as the Precondition for Sustainable Tourism. Nepal Travel Trade Reporter, X (51), 24-25.

Upadhayaya, P.K., \& Sharma S. R. (2010). Sustainable tourism and post-conflict state building. In B.

Upreti B.R., \& Upadhayaya P.K. (2009). Armed Conflict and Tourism: Cost and Consequences in Nepal. In A.C. Settle., I. Niazi., S. Siddiq., \& U.T. Haroon (Eds.), Peace and Sustainable Development in South Asia Issues and Challenges of Globalization (pp. 235 - 261). Lahore: Sang-E-Meel Publications (Sustainable Development Policy Institute).

World Tourism Organisation. 2005. World tourism highlights 2004. [Online] Available from: http://www.worldtourism.org/facts/menu.html

World Tourism Organisation (2003a) Tourism Recovery Committee Meeting - March 2003 http://www.worldtourism.org/mkt/recovery.html [31/3/2007].

World Tourism Organisation (2003b) Tourism and world economy, www.worldtourism.org/facts/trends/economy.htm [17/09/2004]

Woodside, A.G, Lysonski. S (1989), "A General Model of Traveller Destination Choice”, Journal of Travel Research, Vol. 27(4), pp. 8-14. 